\title{
A Systematic Meta-Analysis of Aflatoxin B1 Presence in Red Pepper
}

\author{
Sezen Sevdin ${ }^{1}$, Edanur Çelik ${ }^{2 *}$, Ayşe Nur Çömçe ${ }^{3}$, Nazlı Batar $^{4}$, Ayça Asena Özdemir $^{5}$ \\ ${ }^{1}$ Fenerbahce University, Faculty of Health Sciences, Department of Nutrition and Dietetics, İstanbul, Turkey, (ORCID: 0000-0002-5961-8054), \\ sezen.sevdin@fbu.edu.tr \\ 2* İstanbul Kultur University, Faculty of Health Sciences, Department of Nutrition and Dietetics, İstanbul, Turkey, (ORCID: 0000-0001-9067-2553), \\ dytedacelik@yahoo.com \\ ${ }^{3}$ İstanbul Kultur University, Faculty of Health Sciences, Department of Nutrition and Dietetics, İstanbul, Turkey, (ORCID: 0000-0003-3592-891X), \\ anurcomce@gmail.com \\ 4 İstanbul Kultur University, Faculty of Health Sciences, Department of Nutrition and Dietetics, İstanbul, Turkey, (ORCID: 0000-0001-9527-5709), n.batar@iku.edu.tr

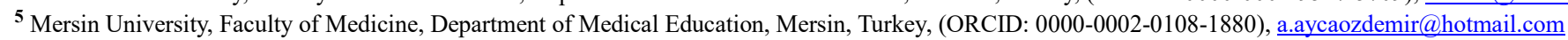

(International Conference on Design, Research and Development (RDCONF) 2021 - 15-18 December 2021)

(DOI: $10.31590 /$ ejosat.1045487)

ATIF/REFERENCE: Sevdin, S., Çelik, E., Çömçe A.N., Batar, N. \& Özdemir, A.A. (2021). A systematic meta-analysis of aflatoxin B1 presence in red pepper. European Journal of Science and Technology, (32), 1162-1167.

\begin{abstract}
Aflatoxins are one of the pollutants that can be isolated from the dried food products, especially spices. Since red pepper is one of the most consumed spices all over the world, this research aimed to estimate the prevalence and concen-tration of aflatoxin B1 (AFB1) in different red pepper spices with the help of a systematic review and meta-analysis. Therefore, the articles published between January 2000 and December 6, 2020, were systematically collected from four well-known databases. In this context, 10 articles containing 455 samples in total among 981 articles were included in the meta-analysis according to the determined inclusion and exclusion criteria. According to the analysis results, the AFB1 prevalence of all studies was determined as $50.8 \%$. The lowest and highest AFB1 concentrations were observed in seasoning paprika Korea $(0.14 \mathrm{mg} / \mathrm{kg})$ and Turkey $(31.13 \mathrm{mg} / \mathrm{kg})$, respectively. The result of this metaanalysis can be used in the evaluation and organization of solution actions to be devel-oped to reduce AFB1 exposure and prevent financial losses through the con-sumption of red pepper spice products.
\end{abstract}

Keywords: AFB1, Contamination, Food safety, Aflatoxin, Red pepper, Meta-analysis.

\section{Kırmızı Biberde Aflatoksin B1 Varlığının Sistematik Derlemesi ve Meta-Analizi}

Öz

Aflatoksinler, kuru gıda ürünlerinden, özellikle baharatlardan izole edilebilen kirleticilerden biridir. Kırmızı biber tüm dünyada en çok tüketilen baharatlardan biri olduğu için bu araştırma, sistematik bir derleme ve meta-analiz yardımıyla farklı kırmızı biber baharatlarında aflatoksin B1 (AFB1) prevalansını ve konsantrasyonunu tahmin etmeyi amaçlamıştır. Bu nedenle Ocak 2000 ile 6 Aralık 2020 arasında yayınlanan makaleler, iyi bilinen dört veri tabanından sistematik olarak toplanmıştır. Bu kapsamda 981 makale arasından toplam 455 örnek içeren 10 makale belirlenen dahil etme ve hariç tutma kriterlerine göre meta-analize dahil edilmiştir. Analiz sonuçlarına göre tüm çalışmaların AFB1 prevalansı \%50.8 olarak belirlenmiştir. En düşük ve en yüksek AFB1 konsantrasyonları sırasıyla Kore (0.14 mg/kg) ve Türkiye'de $(31.13 \mathrm{mg} / \mathrm{kg})$ kırmızı biberlerinde olarak gözlemlenmiştir. Bu meta-analiz sonuçlarının, kırmızı biber baharat ürünlerinin tüketimi yoluyla AFB1 maruziyetini azaltmak ve mali kayıpları önlemek için geliştirilecek çözüm eylemlerinin değerlendirilmesinde ve organizasyonunda kullanılabileceği düşünülmektedir.

${ }^{*}$ Corresponding Author: dytedacelik@,yahoo.com 
Anahtar Kelimeler: AFB1, Kontaminasyon, Gıda güvenliği, Aflatoksin, Kırmızı biber, Meta-analiz.

\section{Introduction}

Food security became a global concern by the growing world population and the aggressively changing climate. Mycotoxins are secondary metabolites that contaminate food and feed and can be formed naturally by different fungi (Marshall et al., 2020). It is known that these natural toxins contaminating soil and food cause negative health effects in humans and animals which also generate economic losses due to the damage that they cause to food (Marshall et al., 2020; Khazaeli et al., 2017). Mycotoxin formation can occur at stages such as the production, harvesting, transportation and storage of agricultural products (Yogendrarajah et al., 2014; Marshall et al., 2020). Among all mycotoxin types, the most widely known mycotoxins are aflatoxins, fumonisins and ochratoxins (Acu \& Ozdestan, 2019). Aflatoxins are one of the well-known mycotoxins and can be produced by different Aspergillus species. Although aflatoxins have different types such as B1, B2, M1, M2, G1 and G2, the form of aflatoxin B1 (AFB1) is thought to have the most toxic effect (Acu \& Ozdestan, 2019; Khazaeli et al., 2017). The International Agency for Research on Cancer (IARC) included aflatoxins in the classification of cancercausing agents first in 1987 (Khazaeli et al., 2017). Today, IARC Monographs Classification of Human Carcinogens defines aflatoxins as group 1 carcinogens (Ostry et al., 2017).

Some factors affecting aflatoxin formation rate of fungus are known as genetic potential, extrinsic factors (such as temperature, $\mathrm{pH}$, redox potential, etc.) the moisture of product and environment, stress or damage of the plant or crop and contamination rate by fungus (Atasoy et al., 2017; Lakkireddy et al., 2014; Gunaydin \& Karaca, 2015). Among them, humidity and temperature can be described as important but also controllable factors. A temperature of $12-47^{\circ} \mathrm{C}$ and relative humidity above $70 \%$ are considered as the optimum conditions for aflatoxinproducing mold growth (Gunaydin \& Karaca, 2015). Foods such as milk and dairy products, dried fruits, grains, and spices are susceptible to contain aflatoxins (Udomkun et al., 2017).

In recent years, the health benefits of spices have been investigated due to their high phytochemical levels. However, it is known that risk assessment of pollutant taken with their consumption is also important (Al Ayoubi et al., 2020). Red pepper (Capsicum annuum L.) is also one of the most popular spices in the global market (Kathuria et al., 2020). Red pepper is mostly grown in countries with tropical or semi-tropical climates. High rainfall, high temperature and relative humidity in growing areas create a favourable environment for mycotoxin production (Santos et al., 2011). Turkey and Mexico are the biggest red pepper producing countries after China (Acaroz, 2019). Although there is a wide area where red pepper is used raw and cooked, the most used type is the spice prepared by drying. Drying can be defined as the dehumidification of food and extends the shelf life by decreasing the water activity of the food. Red peppers are dried by exposure to sunlight outdoors for 8-10 days in Turkey. Although this method is widely used, it is time-consuming and during drying, the pepper is susceptible to contamination from dust, sand chips, soil, and insects (F. Kilic \& Tabanligil, 2020). Red pepper is the most consumed spice after black pepper in the world (Yogendrarajah et al., 2014). In this context, when evaluated in terms of public health and commercial needs, it is an important issue that red pepper is free from pollutants (Reinholds et al., 2017).
The Food and Agriculture Organization (FAO) determined the maximum level of aflatoxin that can be found in red peppers as $1 \mathrm{ppb}$ (FAO, 2000). In analysing aflatoxins, different methods such as ELISA (Enzyme-Linked Immunosorbent Assay), thinlayer chromatography (TLC), capillary electrophoresis and highperformance liquid chromatography (HPLC) can be used (Acu \& Ozdestan, 2019).

Aflatoxin levels in red peppers have been studied in many geographies (Koutsias et al., 2020; Kim et al., 2020; Cuce, 2020; Acaroz, 2019; Fofana-Diomande et al., 2019). In this study, the aim was to make a systematic review and meta-analysis of the literature in different geographies studied on the level of AFB1, which is known as the most poisonous aflatoxin type in red pepper. It is aimed to compare the determination methods used in the studies, the prevalence of countries and AFB1 concentrations.

\section{Material and Method}

\subsection{Search Strategy}

The articles to be used in this study were collected systematically from Science Direct, Scopus, Google Scholar, Springer Link and Web of Science databases by the researchers.

The keywords used in each database and the limitations applied were as followed: a TI-A-KE (Title-Abstract-Keyword) search was performed using the keywords "aflatoxin b1" AND "red pepper" on Science Direct, Scopus, Springer Link, Web of Science databases. On Google Scholar, a search was performed using the keywords "aflatoxin b1" AND "red pepper" to exclude patents and citations in the form of TI-A-KE-FT (Title-AbstractKeyword-Full Text). The reference lists of the included articles were also examined to identify suitable articles to include.

\subsection{Inclusion Criteria}

The criteria for inclusion in this study are as follows; (1) the language of the publication is English; (2) reporting the mean concentration of AFB1 in red peppers; (3) reporting the AFB1 range in red pep-pers; (4) to be an original research article; (5) full text is available; (6) the summary of the listed arti-cles to be within the subject when examined. Mendeley Desktop 1.19.4 version (Elsevier, Amsterdam, Netherlands) was used to organize the included articles.

\subsection{Data Filtering}

From each article, year of publication, type of paprika used, average AFB1 concentration $(\mu \mathrm{g} / \mathrm{kg})$, AFB1 range $(\mu \mathrm{g} / \mathrm{kg})$, a standard deviation of concentration $(\mu \mathrm{g} / \mathrm{kg})$, total and positive sample number, country of study, analysis method, Lower Limit of Detection (LOD) per kilogram and Limit of Quanti-fication (LOQ) $(\mu \mathrm{g} / \mathrm{kg})$ data were obtained and reported in Microsoft Excel software. Figure 1 shows the flow of data exclusion and filtering according to the criteria. 


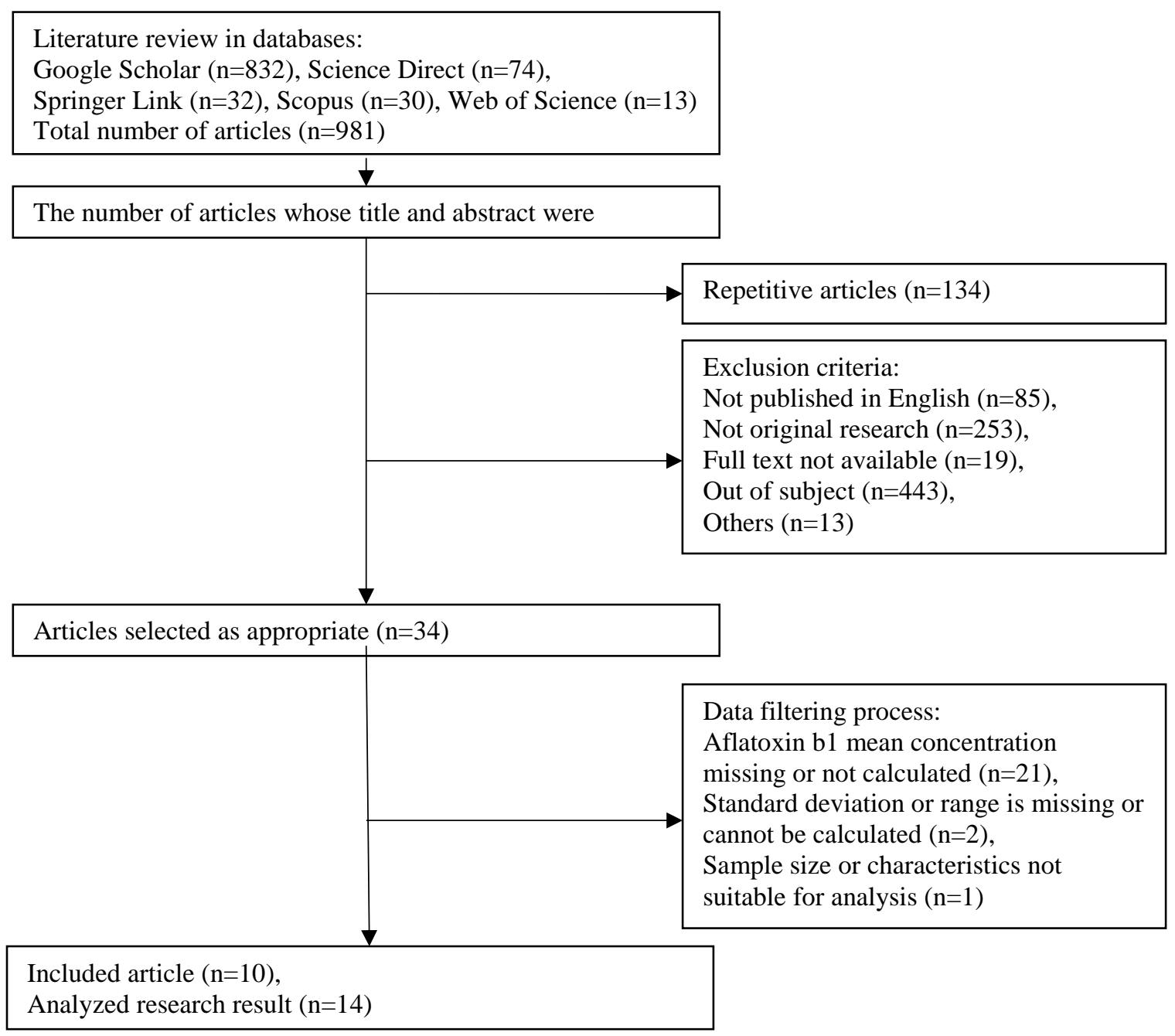

Figure 1. Data exclusion and filtering flowchart. This figure shows the flow of data exclusion and filtering according to the criteria.

\subsection{Statistical Analysis}

The meta-analysis results of the studies were made in the Comprehensive Meta-Analysis (trial) pro-gram. Positive case numbers and total case numbers were used according to the ratio calculation for a single group, and overall prevalence values were calculated. Random or fixed effect models are preferred according to their heterogeneity. Meta-regression models were created according to the countries and the device used. The reference country for countries is Iran and for devices, LC-MS/MS have been chosen. A funnel plot and Egger test were applied to investigate publication bias.

\section{Results and Discussion}

\subsection{Selection of Studies and Study Bias}

A total of 981 articles (Google Scholar $(n=832)$, Science Direct $(n=74)$, Scopus $(n=30)$, Web of Science $(n=13))$ were subjected to title and content review in databases. At this stage, 134 repetitive articles, 85 non-English articles, 253 non-original articles, 19 studies without full text, 443 studies that were offtopic, and 13 articles due to other reasons such as internet page not working, content unavailable, index result, etc. were excluded. Figure 1 shows the data inclusion and exclusion process through the study.
At the data filtering stage, 21 articles that did not contain AFB1 mean, 2 studies that did not contain a standard deviation or AFB1 concentration range and 1 article containing an unsuitable sample for analysis were excluded. In some of the remaining 10 articles, different measurement and quantification techniques were used on the same pepper samples. Therefore, in total, 14 research results were analysed with statistical analysis tool.

A Funnel plot was drawn, and the Egger test was performed to determine the study bias. According to the Funnel graph and Egger test result $(p=0.837)$ shown in Figure 2, publication bias was not detected.

Heterogeneity between studies was determined $\left(I^{2}: 99.97\right.$, $\mathrm{p}<0.05$ ), so a random-effects model was used to combine studies and calculate the pooled data. 


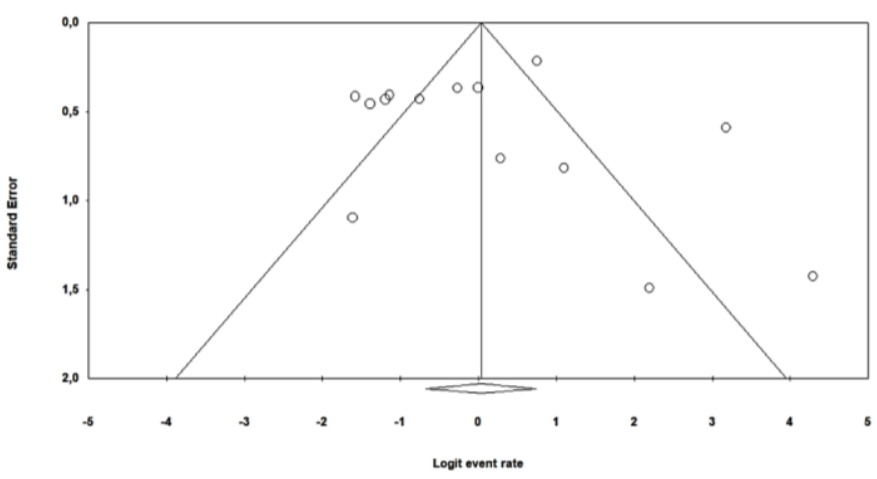

Figure 2.The funnel plot is used to determine the study bias.

\subsection{Aflatoxin B1 Determination Techniques}

Analytical methods are expected to be sensitive, specific, and easily applicable for detection and quantification of aflatoxins. Various methods, including HPLC, ELISA, and LC-MS/MS, have advantages and limitations over each other regarding their use in the analysis of aflatoxins in foods (Wacoo et al., 2014; Aksoy et al., 2016). ELISA is a faster and easier method to apply, while HPLC is known as a method with higher sensitivity and selectivity (Beyene et al., 2019).

Although AFB1 can be determined using various techniques, HPLC, ELISA and LC-MS / MS were used in the aforamentioned studies. Table $1 \mathrm{~S}$ lists the techniques used in the selected studies. While 7 of them were performed using HPLC, 6 of them were obtained using ELISA and 1 with LC-MS/MS method. Of these techniques, HPLC, ELISA and LC-MS/MS were used in 50\%, $43 \%$ and $7 \%$ of the studies respectively. All the red peppers analysed by HPLC method by Cavus et al. (2018) are positive; the mean level of total AFB1 was found to be $4.3 \pm 5.7 \mu \mathrm{g} / \mathrm{kg}$. Colak et al. (2006) used the ELISA method in the analysis of total AFB1 concentration in red peppers and found that it was $1.23 \pm 2.77$ $\mu \mathrm{g} / \mathrm{kg}$. In the same study, the result was found to be $1.10 \pm 2.55$ $\mu \mathrm{g} / \mathrm{kg}$ in the analysis performed by the HPLC method in red peppers. Çolak et al. (2006) examined the red scale samples with different methods in this study and the results of HLPC and ELISA analysis were detected at the levels of $6.68 \pm 10.92$ and $7.22 \pm 11.78 \mu \mathrm{g} / \mathrm{kg}$, respectively. Similar to the other studies comparing the results of HPLC and ELISA methods using different foodstuffs, the findings show that the analysis method had no effect on the pooled results $(\mathrm{p}>0.05)$ (Kos et al., 2016; Beyene et al., 2019; Pirestani et al., 2011).

\subsection{Aflatoxin B1 Prevalence of Countries}

Spice markets today offer red pepper in various forms (red pepper, dried red pepper, dark red powder pepper, etc.). In this study, studies in which AFB1 levels were analysed in red peppers in spice form were examined.

The prevalence of AFB1 in red pepper spice in different countries (2000-2020) is shown in Table 1 . The country ranking of the AFB1 prevalence in samples is Iran (100\%)> Turkey $(52.1 \%)>$ Korea $(17.1 \%)>$ Japan $(16.7 \%)$. Confidence intervals could not be calculated since Iran, Korea and Japan only had one study. Prevalence was calculated with reference to Iran (as it has a $100 \%$ rate). The prevalence of AFB1 in all studies was found to be $50.8 \%$ (95\% CI 33.8-67.7).
Table 1. Prevalence and confidence interval (CI) by country

\begin{tabular}{lcc}
\hline Country & Prevalence $(\mathbf{9 5} \%$ CI $)$ & CI \\
\hline Iran & $\% 100$ & $*$ \\
\hline Turkey & $\% 52.1$ & $\% 34.5-\% 69.2$ \\
\hline Korea & $\% 17.1$ & $*$ \\
\hline Japan & $\% 16.7$ & $*$ \\
\hline
\end{tabular}

\subsection{Aflatoxin B1 Concentration}

With globalization, the ease of access to spices and the popularity of spices are increasing. (Matthews \& Jack, 2011). Red pepper, one of the widely used spice types, is a product suitable for aflatoxin formation due to its low mycotoxic quality (Kilichan \& Calhan, 2015; Waśkiewicz et al., 2013). In this meta-analysis, the studies from Iran, Japan, Korea, and Turkey, on red pepper spice and AFB1 contamination were evaluated Among the products analysed for AFB1 levels, there were red peppers, red chili peppers, paprika, dried red peppers, ground red pepper and dark red pepper. In some of the studies included in the study, the individual aflatoxin contents of the samples were given instead of the average aflatoxin amount. In studies where such mean can be calculated, means and standard deviations are calculated and used (Colak et al., 2006; Cavus et al., 2018). The studies at which the mean and standard deviation were not given or calculated were not used in calculating the mean concentration (Barani et al., 2016; Ozturk, 2017; Sugita-Konishi et al., 2010; Tosun \& Arslan, 2013). When these results are added, the average AFB1 content is calculated as $6.61(\mu \mathrm{g} / \mathrm{kg})$.

Countries specify the maximum contamination limits in their legislation for food suitable for consumption. AFB1 maximum limit for spices in Iran, Korea and Japan are respectively; 5, 10 and $10 \mu \mathrm{g} / \mathrm{kg}$ (FAO, 2003). In the study conducted in Iran according to Table 1, AFB1 was detected in $100 \%$ of the red pepper spice samples with an average concentration of 15.51 $\mu \mathrm{g} / \mathrm{kg}$ (Barani et al., 2016). In the study conducted in Japan, AFB1 in red pepper spice was found at an average concentration of 0.17 $\mu \mathrm{g} / \mathrm{kg}$ (Sugita-Konishi et al., 2010). This value has been determined as $0.14 \mu \mathrm{g} / \mathrm{kg}$ in powdered red pepper samples in Korea (Cho et al., 2008).

According to Article 8 Clause 1 of the Turkish Food Codex Contaminants Regulation, the maximum AFB1 limit attributed to red pepper spice is limited to $5 \mu \mathrm{g} / \mathrm{kg}$ (Prime Ministry General Directorate of Legislation Development and Publication, 2011). In a study conducted by Ardiç et al. in Turkey, $96 \%$ of the dark red powdered pepper samples that were studied had a total AFB1 mean level of $1.9 \mu \mathrm{g} / \mathrm{kg}$ and a standard deviation of $4.2 \mu \mathrm{g} / \mathrm{kg}$ (Ardic et al., 2008). In addition, in another study in which the red pepper and red chili pepper samples were analysed in Turkey, the average AFB1 concentrations determined as 31.13 and 13.37 $\mu \mathrm{g} / \mathrm{kg}$, respectively (Tosun \& Arslan, 2013).

\subsection{Limitations of the Study}

Lack of similar sample types, sample numbers, and sampling procedures in research articles, non-similar result presentation and lack of main statistical results such as mean, standard deviation or error, etc., the difficulties to reach the full text or most related articles through the internet search can be stat-ed as the limitation of this meta-analysis. Due to these reasons, although 
the reviewed article number is high, selected, and analysed articles number is much less.

\section{Conclusion and Recommendations}

In this study, the prevalence and concentration of red pepper spice products were meta-analysed according to different analysis methods and countries. The highest prevalence of AFB1 registered in the analysed red pepper spice is in Iran and Turkey; the values corresponding to the lowest prevalence are attributed to the red pepper spices researched in Korea and Japan. In addition, it is shown that the maximum AFB1 concentration limits specified in the legislation for spices are exceeded in some countries based on red pepper products. The AFB1 concentration in the red chilli peppers that are sold in Turkey extensively vary from sample to sample (Barani et al., 2016; Colak et al., 2006; Kilic S et al., 2018; Tosun \& Arslan, 2013). This is primarily attributed to drying formation and storage stages of the plant. Besides, harvesting, packaging and transportation stages are considered as processes that prepare the ground for contamination (Hashem \& Alamri, 2010). All the wrong practices that predispose to AFB1 contamination and the sale of red pepper spices that do not meet the criteria in the markets show that this uncontrolled marketing poses a threat to public health.

Therefore, it is recommended to consider food health management plans and food legislation to eliminate the health threats of uncontrolled sales of spices. The result of a metaanalysis can be used in the evaluation and organization of actions which can be developed to reduce the exposure to AFB1 because of consumption of red pepper spice products and to prevent financial losses. However, it is important to increase the number of studies on the subject in order to confirm and generalize the result of this meta-analysis, which studied the prevalence and concentration of AFB1 in red pepper spice products.

\section{References}

Acaroz, U. (2019). Determination of the total aflatoxin level in red pepper marketed in Afyonkarahisar, Turkey. Fresenius Environmental Bulletin, 28(4A), 3276-3280.

Acu, M., \& Ozdestan Ocak, Ö. (2019). The methods of analysis used in the determination of aflatoxin levels in foods (In Turkish). Sinop University Journal of Natural Sciences, 4(2), 168-181. DOI: https://doi.org/10.33484/sinopfbd.537820

Aksoy, A., Atmaca, E., Yazici, F., Güvenc, D., Gül, O., \& Dervisoglu, M. (2016). Comparative analysis of aflatoxin M1 in marketed butter by ELISA and HPLC. Journal of the Faculty of Veterinary Medicine, Kafkas University, 22(4), 619-621. DOI: https://doi.org/10.9775/kvfd.2016.15115

Al Ayoubi, M., Solfrizzo, M., Gambacorta, L., Watson, I., \& El Darra, N. (2020). Risk of exposure to aflatoxin b1, ochratoxin $\mathrm{a}$, and fumonisin b1 from spices used routinely in Lebanese cooking. Food and Chemical Toxicology, 147, 111895. DOI: https://doi.org/10.1016/j.fct.2020.111895

Ardic, M., Karakaya, Y., Atasever, M., \& Durmaz, H. (2008). Determination of aflatoxin b1 levels in deep-red ground pepper (isot) using immunoaffinity column combined with ELISA. Food and Chemical Toxicology, 46(5), 1596-1599. DOI: https://doi.org/10.1016/j.fct.2007.12.025

Atasoy, A. F., Hayoğlu, İ. A., Korkmaz, A., Kara, E., \& Yildirim, A. (2017). A research on the determination of aflatoxin content of traditional home-made isot (In Turkish). Harran Journal of Agricultural and Food Science, 21(1), 35-40.

Barani, A., Nasiri, Z., \& Jarrah, N. (2016). Natural occurrence of aflatoxins in commercial pepper in Iran. Food and Agricultural Immunology, 27(4), 570-576. DOI: https://doi.org/10.1080/09540105.2016.1148124

Beyene, A. M., Du, X., Schrunk, D., Ensley, S., \& Rumbeiha, W. K. (2019). High-performance liquid chromatography and enzyme-linked immunosorbent assay techniques for detection and quantification of aflatoxin b1 in feed samples: a comparative study. BMC Research Notes, 12(1). DOI: https://doi.org/10.1186/s13104-019-4538-z

Cavus, S., Tornuk, F., Sarioglu, K., \& Yetim, H. (2018). Determination of mold contamination and aflatoxin levels of the meat products/ingredients collected from Turkey market. Journal of Food Safety, 38(5), e12494. DOI: https://doi.org/10.1111/jfs. 12494

Cho, S. H., Lee, C. H., Jang, M. R., Son, Y. W., Lee, S. M., Choi, I. S., Kim, S. H., \& Kim, D. B. (2008). Aflatoxin contamination in spices and processed spice products commercialized in Korea. Food Chemistry, 107(3), 12831288. DOI: https://doi.org/10.1016/j.foodchem.2007.08.049

Colak, H., Bingöl, E. B. \& Nazli, B. (2006). Determination of aflatoxin contamination in red-scaled, red and black pepper by ELISA and HPLC. Journal of Food and Drug Analysis, 14(3), 292-296. DOI: https://doi.org/10.38212/22246614.2476

Cuce, M. (2020). Incidence of aflatoxins, ochratoxin A, zearalenone, and deoxynivalenol in food commodities from Turkey. Journal of Food Safety, 40(6), 1-13. DOI: https://doi.org/10.1111/jfs. 12849

FAO. (2000). Guidance for industry: action levels for poisonous or deleterious substances in human food and animal feed. Retrieved from: https://www.fda.gov/regulatoryinformation/search-fda-guidance-documents/guidanceindustry-action-levels-poisonous-or-deleterious-substanceshuman-food-and-animal-feed\#afla (Accessed 15.01.2021)

FAO. (2003). Mycotoxin Regulations for Food and Feeding stuffs for Countries Surveyed. Retrieved from: http://www.fao.org/3/a-y5499e.pdf (Accessed 15.01.2021)

Fofana-Diomande, A., Kouakou, K. J.-M., Aboua, K. N., Traore, K. S., \& Dembele, A. (2019). Study of the contamination of some spices from Côte d'ivoire by mycotoxins (AFB1 and OTA). Journal of Chemical, Biological and Physical Sciences, $\quad 9(3), \quad 389-399$. $\quad$ DOI: https://doi.org/10.24214/jcbps.B.9.3.38999

Gunaydin, Ş., \& Karaca, H. (2015). Use of natural extracts in control of mold contamination and mycotoxin production (In Turkish). Academic Food Journal, 13(2), 173-182.

Hashem, M., \& Alamri, S. (2010). Contamination of common spices in Saudi Arabia markets with potential mycotoxinproducing fungi. Saudi Journal of Biological Sciences, 17(2), 167-175. DOI: https://doi.org/10.1016/j.sjbs.2010.02.01

Kathuria, S., Mathur, P., Gitau, C. M. W., Khanna, A., Manghnani, R., Rizwan, N., \& Duch, E. (2020). Strengthening crossborder value chains opportunities for India and Bangladesh. Retrieved from: http://documents 1.worldbank.org/curated/en/234891583753 $576911 / \mathrm{pdf} /$ Strengthening-Cross-Border-Value-ChainsOpportunities-for-India-and-Bangladesh.pdf (Accessed 15.01.2021)

Khazaeli, P., Mehrabani, M., Heidari, M. R., Asadikaram, G., \& Lari Najafi, M. (2017). Prevalence of aflatoxin contamination in herbs and spices in different regions of Iran. Iranian Journal of Public Health, 46(11), 1540-1545.

Kim, S. J., Cheon, S. H., Kim, S. H., \& Seo, H. Y. (2020). 
Determination of aflatoxins in red pepper and kimchi by ultra-high-performance liquid chromatography with fluorescence detection. Analytical Letters, 53(7), 1087-1096. DOI: https://doi.org/10.1080/00032719.2019.1696354

Kilic, F., \& Tabanligil Calam, T. (2020). Determination of drying and rehydration kinetics of red capia pepper (Capsicum Annuum 1.), energy analysis of drying process. Dokuz Eylul University Faculty of Engineering Journal of Science and Engineering, 22(65), 343-352. DOI: https://doi.org/10.21205/deufmd.2020226503

Kilic, S., Cam, I. B., Tongur, T., \& Kilic, M. (2018). Health risk assessment of exposure to heavy metals and aflatoxins via dietary intake of dried red pepper from marketplaces in Antalya, Southern Turkey. Journal of Food Science, 83(10), 2675-2681. DOI: https://doi.org/10.1111/1750-3841.14322

Kilichan, R., \& Calhan, H. (2015). Spices the Magic of Cuisines: Determination of spice consumption habits in Kayseri Province (In Turkish). Journal of Tourism and Gastronomy Studies, 3(2), 40-47.

Kos, J., Hajnal, E. J., Jajić, I., Krstović, S., Mastilović, J., Šarić, B., \& Jovanov, P. (2016). Comparison of ELISA, HPLC-FLD and HPLC-MS/MS methods for determination of aflatoxin M1 in natural contaminated milk samples. Acta Chimica Slovenica, 63(4), 747-756. https://doi.org/10.17344/acsi.2016.2451

Koutsias, I., Kollia, E., Makri, K., Markaki, P., \& Proestos, C. (2020). Occurrence and risk assessment of aflatoxin b1 in spices marketed in Greece. Analytical Letters. DOI: https://doi.org/10.1080/00032719.2020.1832509

Lakkireddy, K., Kondapalli, K., \& Sambasiva Rao, K. R. S. (2014). Aflatoxins in food and feed: the science of safe food. Journal of Food Science and Technology, 3(2), 6-11.

Marshall, H., Meneely, J. P., Quinn, B., Zhao, Y., Bourke, P., Gilmore, B. F., Zhang, G., \& Elliott, C. T. (2020). Novel decontamination approaches and their potential application for post-harvest aflatoxin control. Trends in Food Science and Technology, 106, 489-496. DOI: https://doi.org/10.1016/j.tifs.2020.11.001

Matthews, M., \& Jack, M. (2011). Spices and herbs for home and market. Retrieved from: http://www.fao.org/3/i2476e/i2476e00.pdf (Accessed 15.01.2021)

Ostry, V., Malir, F., Toman, J., \& Grosse, Y. (2017). Mycotoxins as human carcinogens-the IARC monographs classification. Mycotoxin Research, 33(1), 65-73. DOI: https://doi.org/10.1007/s12550-016-0265-7

Ozturk Yilmaz, S. (2017). The contamination rate of aflatoxins in ground red peppers, dried figs, walnuts without shell and seedless black raisins commercialized in Sakarya City Center, Turkey. Italian Journal of Food Science, 29(4), 591-598.

Pirestani, A., Tabatabaei, S. N., Fazeli, M. H., Antikchi, M., \& Baabaei, M. (2011). Comparison of HPLC and Elisa for determination of aflatoxin concentration in the milk and feeds of dairy cattle. Journal of Research in Agricultural Science, 7(1), 71-78.

Prime Ministry General Directorate of Legislation Development and Publication. (2011, December 29). Turkish Food Codex Contaminants Regulation (In Turkish). Official Newspaper No:28157. Retrieved from: https://www.resmigazete.gov.tr/eskiler/2011/12/20111229M 3-8.htm (Accessed 15.01.2021)

Reinholds, I., Pugajeva, I., Bavrins, K., Kuckovska, G., \& Bartkevics, V. (2017). Mycotoxins, pesticides and toxic metals in commercial spices and herbs. Food Additives and Contaminants: Part B Surveillance, 10(1), 5-14. DOI: https://doi.org/10.1080/19393210.2016.1210244

Santos, L., Marín, S., Mateo, E. M., Gil-Serna, J., Valle-Algarra, F. M., Patiño, B., \& Ramos, A. J. (2011). Mycobiota and cooccurrence of mycotoxins in capsicum powder. International Journal of Food Microbiology, 151(3), 270-276. DOI: https://doi.org/10.1016/j.ijfoodmicro.2011.09.011

Sugita-Konishi, Y., Sato, T., Saito, S., Nakajima, M., Tabata, S., Tanaka, T., Norizuki, H., Itoh, Y., Kai, S., Sugiyama, K., Kamata, Y., Yoshiike, N., \& Kumagai, S. (2010). Exposure to aflatoxins in Japan: risk assessment for aflatoxin B1. Food Additives and Contaminants, 27(3), 365-372. DOI: https://doi.org/10.1080/19440040903317497

Tosun, H., \& Arslan, R. (2013). Determination of aflatoxin B1 levels in organic spices and herbs. The Scientific World Journal, 2013, 1-4. DOI: https://doi.org/10.1155/2013/874093

Udomkun, P., Wiredu, A. N., Nagle, M., Müller, J., Vanlauwe, B., \& Bandyopadhyay, R. (2017). Innovative technologies to manage aflatoxins in foods and feeds and the profitability of application - A review. Food Control, 76(2017), 127-138. DOI: https://doi.org/10.1016/j.foodcont.2017.01.008

Wacoo, A. P., Wendiro, D., Vuzi, P. C., \& Hawumba, J. F. (2014). Methods for detection of aflatoxins in agricultural food crops. Journal of Applied Chemistry, 12(1), 1-15. DOI: https://doi.org/10.1155/2014/706291

Waśkiewicz, A., Beszterda, M., Bocianowski, J., \& Goliński, P. (2013). natural occurrence of fumonisins and ochratoxin a in some herbs and spices commercialized in Poland analyzed by UPLC-MS/MS method. Food Microbiology, 36(2), 426-431. DOI: https://doi.org/10.1016/j.fm.2013.07.006

Yogendrarajah, P., Jacxsens, L., De Saeger, S., \& De Meulenaer, B. (2014). Co-occurrence of multiple mycotoxins in dry chili (Capsicum Annum L.) samples from the markets of Sri Lanka and Belgium. Food Control, 46, 26-34. DOI: https://doi.org/10.1016/j.foodcont.2014.04.043 